\title{
ACCELERATING THE IMPLEMENTATION OF THE CLEAN DEVELOPMENT mechanism in South Africa
}

\author{
Grant Little, Tudor Maxwell and Margie Sutherland \\ Gordon Institute of Business Science, University of Pretoria
}

\begin{abstract}
One of the responses to the threat of global warming is the Kyoto Protocol and the associated Clean Development Mechanism (CDM) to reduce greenhouse gases. South Africa is an ideal country for the implementation of industrial CDM projects, yet lags behind many other countries. This qualitative research determines the factors that cause South Africa to lag other developing countries in the implementation of industrial CDM projects and the interventions that will have the most impact on accelerating implementation. The research involved interviews with 30 experts involved in the South African CDM process. The results identify the factors perceived to be facilitating and inhibiting the use of CDM opportunities and a framework for CDM practitioners to develop an implementation strategy within South African industry is established.
\end{abstract}

Abstract

JEL Q56

\section{Introduction}

One of the primary responses to global warming has been the Kyoto Protocol (United Nations, 1997). Following the Kyoto Protocol was the Marrakech Accord (United Nations, 2001) which allowed developing countries to implement Clean Development Mechanism (CDM) projects in order to assist developed countries to meet their targets set under the Protocol. To motivate non-Annex I countries (or developing countries) to participate in the CDM they are awarded technology transfer for the projects, foreign funding for the projects and the possibility of trading the carbon credits gained from the projects with Annex I countries. The Kyoto Protocol classified South Africa as a non-Annex I country and it is therefore eligible to implement CDM projects, whereas developed countries (or those listed in Annex I of the protocol) are not eligible for CDM projects and have to meet their stipulated carbon emission targets by other mechanisms such as emission reduction. CDM projects are projects that reduce the gaseous emissions of carbon dioxide $\left(\mathrm{CO}_{2}\right)$ that increase global warming - the so called greenhouse gases (GHG). Projects need to comply with a number of criteria under the Marrakech Accord such as contributing to sustainable development and passing additionality tests, before they can be registered with the United Nations as a CDM project. The rules for CDM were finalised in terms of the Marrakech Accord (United Nations, 2001), and came into effect in February 2005 when the Kyoto Protocol was ratified by the required number of signatories.

South Africa seems an ideal candidate to host CDM projects (Greene, 2005; Jung, 2006; Greene, 2006) and yet it continues to lag behind other non-Annex I countries like India, China, Brazil and even Honduras and Chile in the number of projects that are implemented. As of August 2006 a total of 996 CDM projects had been logged with the United Nations, of which only 12 were from South Africa (United Nations Environment Programme, 2006). The contemporary press often points out this lack. A typical example of such an article is: "SA tardy in signing up for carbon credits" (Njobeni, 2006). 


\section{2}

\section{Research rationale}

This qualitative research sought to ascertain the various factors that influence South African industries both positively and negatively when considering implementing projects under the United Nations CDM. The purpose was to highlight positive factors in future project proposals and the negative factors could be clearly identified and mitigated by project developers and to develop interventions that would have the most impact on accelerating the implementation of these projects. The research was limited to industrial non-sink projects.
3

\section{Literature review}

Jung (2006) analysed 114 countries that had the potential to host CDM projects in which South Africa was identified as a "very attractive" potential host country. Other countries identified as very suitable included China, Brazil and India. This review seeks to understand the facilitating and inhibiting factors which impact on the establishment of CDM projects. This is in order to build a foundation for the research to understand why, although potentially attractive, South Africa is lagging behind other developing countries in the successful implementation of CDM opportunities. The literature is presented in tabular format in order to make the categories in the literature clear.

\subsection{Facilitating factors}

A range of factors have been identified in the literature that make the implementation of $\mathrm{CDM}$ projects attractive. These are shown in the table below:

Table 1

Facilitating factors

\begin{tabular}{|l|l|l|}
\hline Issues & Sources & Reasons \\
\hline $\begin{array}{l}\text { Finance available } \\
\text { from investors }\end{array}$ & $\begin{array}{l}\text { Maruyama (1999); Nelson(2004); } \\
\text { Greene (2005); The Climate Group } \\
\text { (2005); Dagoumas, Papagiannis } \\
\text { and Dokopoulos (2006); Ellis, } \\
\text { Winkler, Corfee-Morlot and } \\
\text { Gagnon-Lebrun (2007); } \\
\text { Greene (2006) and Jung (2006) }\end{array}$ & $\begin{array}{l}\text { Finance is by far the most widely cited of the factors } \\
\text { encouraging industry to implement CDM projects. } \\
\text { The availability of finances to industry provides } \\
\text { capital for investment into projects that would } \\
\text { not otherwise have been considered if traditional } \\
\text { channels of finance had to be considered. }\end{array}$ \\
\hline $\begin{array}{l}\text { Income from the } \\
\text { sale of carbon } \\
\text { credits }\end{array}$ & $\begin{array}{l}\text { Matsushashi, Fujisawa, Mitamura, } \\
\text { Momobayashi and Yoshida (2004); } \\
\text { Bond and Dada (2005); Greiner } \\
\text { and Michaelowa (2003); Greene } \\
\text { (2005); Dagoumas et al. (2006) } \\
\text { and Ellis et al. (2007) }\end{array}$ & $\begin{array}{l}\text { The profitability of CDM can be viewed as potentially } \\
\text { both positive and negative. However, the trade } \\
\text { of carbon credits is seen as being economically } \\
\text { profitable. Capoor and Ambrosi (2006) evaluated the } \\
\text { carbon market to be in excess of US\$ 21.5 billion at } \\
\text { the end of September 2006. }\end{array}$ \\
\hline $\begin{array}{l}\text { Technology } \\
\text { transfer }\end{array}$ & $\begin{array}{l}\text { Spalding-Fecher (2002); Nelson } \\
\text { (2004) and Sonneborn (2004) }\end{array}$ & $\begin{array}{l}\text { One of the goals of the Kyoto Protocol was to } \\
\text { promote technology transfer between Annex I and } \\
\text { non-Annex I countries. }\end{array}$ \\
\hline $\begin{array}{l}\text { Corporate } \\
\text { governance } \\
\text { and the role of } \\
\text { stakeholders }\end{array}$ & $\begin{array}{l}\text { Cogan (2006) and Maxwell (2006) } \\
\text { The influence of corporate governance has increased, } \\
\text { following guidelines and legislation like the King II } \\
\text { Report in South Africa and Sarbanes-Oxley Act.These } \\
\text { play a role in encouraging companies to implement } \\
\text { measures to respond to climate change including CDM. }\end{array}$ \\
\hline
\end{tabular}




\begin{tabular}{|l|l|l|}
\hline $\begin{array}{l}\text { National } \\
\text { infrastructure in } \\
\text { place }\end{array}$ & $\begin{array}{l}\text { Jung (2006); Spalding-Fecher } \\
(2002) \text { and Greene (2006) }\end{array}$ & $\begin{array}{l}\text { Prequisites of signatories of the Kyoto Protocol; } \\
\text { ratification of the Kyoto Protocol; national CDM } \\
\text { authority (Designated National Authority - DNA) } \\
\text { installed "timely" and a national strategy study on } \\
\text { greenhouse gas emissions completed. }\end{array}$ \\
\hline $\begin{array}{l}\text { Improved } \\
\text { energy security } \\
\text { \& efficiency in } \\
\text { large emission } \\
\text { sources }\end{array}$ & $\begin{array}{l}\text { Greene,(2005); Davidson; } \\
\text { Soknæ; Huq; Kok; Metz; }\end{array}$ & $\begin{array}{l}\text { Large industrial emitters find CDM an attractive } \\
\text { option. Energy is a major problem in Africa, and } \\
\text { CDM could assist in moving the continent towards } \\
\text { future energy security. }\end{array}$ \\
\hline $\begin{array}{l}\text { Political stability } \\
\text { and economic } \\
\text { growth }\end{array}$ & Greene (2006) & $\begin{array}{l}\text { Stable political structures and extended periods of } \\
\text { economic growth create a prime environment for } \\
\text { CDM implementation. }\end{array}$ \\
\hline
\end{tabular}

\subsection{Inhibiting factors}

Far more has been written in the literature about the factors inhibiting the CDM process than about the factors that are seen to have a positive influence. The range of potentially inhibiting factors are shown in the following table.

Table 2

Inhibiting factors

\begin{tabular}{|c|c|c|}
\hline Issues & Sources & Reasons \\
\hline $\begin{array}{l}\text { Relatively low energy } \\
\text { prices }\end{array}$ & $\begin{array}{l}\text { Kim (2003) and Greene } \\
(2006)\end{array}$ & $\begin{array}{l}\text { Cheap power creates a perverse disincentive to } \\
\text { investors in clean energy projects. }\end{array}$ \\
\hline $\begin{array}{l}\text { The lack of sufficient } \\
\text { capacity in the CDM } \\
\text { process }\end{array}$ & Greene (2005) & $\begin{array}{l}\text { Although capacity building plays an important part } \\
\text { in accelerating the CDM process there is a concern } \\
\text { over all talk and no action. }\end{array}$ \\
\hline $\begin{array}{l}\text { Additionality evidence } \\
\text { requirements for } \\
\text { projects }\end{array}$ & $\begin{array}{l}\text { Kamel (2005); World Business } \\
\text { Council for Sustainable } \\
\text { Development and World } \\
\text { Resources Institute (2004) and } \\
\text { Greiner and Michaelowa (2003) }\end{array}$ & $\begin{array}{l}\text { This criterion requires evidence whether a project } \\
\text { has resulted in GHG emission reductions or } \\
\text { removals in addition to what would have occurred } \\
\text { in its absence is difficult to prove. }\end{array}$ \\
\hline $\begin{array}{l}\text { Conservative } \\
\text { approaches by industry }\end{array}$ & Greene (2006) & $\begin{array}{l}\text { South African industry is generally more conservative } \\
\text { in embracing changes than many other countries are. }\end{array}$ \\
\hline $\begin{array}{l}\text { Price volatility of } \\
\text { carbon credits (CERs) }\end{array}$ & $\begin{array}{l}\text { Maruyama (1999) and Viguier } \\
(2004)\end{array}$ & $\begin{array}{l}\text { Since carbon became a tradable commodity the } \\
\text { price for } 1 \text { ton of carbon equivalent has fluctuated } \\
\text { from below } € 10 \text { to over } € 30 \text {. This volatility has } \\
\text { caused project developers to be cautious }\end{array}$ \\
\hline $\begin{array}{l}\text { Uncertainty regarding } \\
\text { Kyoto Protocol post- } \\
2012\end{array}$ & Greene (2005) Greene (2006) & $\begin{array}{l}\text { The Kyoto Protocol (United Nations, 1997) only } \\
\text { exists until 2012. Thereafter a new mechanism } \\
\text { needs to be developed. Participants in the CDM } \\
\text { market need to move fast if they are to maximise the } \\
\text { number of CERs they create by 2012. Uncertainty } \\
\text { regarding what follows } 2012 \text { is a major obstacle to } \\
\text { the entire CDM process. }\end{array}$ \\
\hline
\end{tabular}




\begin{tabular}{|c|c|c|}
\hline $\begin{array}{l}\text { Ineffective } \\
\text { Government policies } \\
\text { and leadership }\end{array}$ & $\begin{array}{l}\text { Nelson (2004) and Greene } \\
(2006)\end{array}$ & $\begin{array}{l}\text { A number of potential CDM projects are overlooked } \\
\text { because of the concerns around national sustainable } \\
\text { development targets and other socio-economic } \\
\text { issues, EIA processes and protracted deregulation of } \\
\text { the energy sector. }\end{array}$ \\
\hline $\begin{array}{l}\text { The bureaucratic } \\
\text { processes and overall } \\
\text { complexity of the } \\
\text { CDM process }\end{array}$ & $\begin{array}{l}\text { Maruyama (1999) and } \\
\text { Greene(2005) }\end{array}$ & \\
\hline High transaction costs & $\begin{array}{l}\text { Michaelowa, Stronzik, } \\
\text { Eckermann and Hunt (2003) } \\
\text { and Viguier (2004) }\end{array}$ & $\begin{array}{l}\text { The CDM process has a number of costs involved } \\
\text { in the process, they tally up to around } € 100,000 \text { in } \\
\text { total. Projects need to have a fairly large emission } \\
\text { reduction to be viable. For developing countries to } \\
\text { embrace the greenhouse gas emission reduction, tax } \\
\text { incentives need to be provided as a mitigation of the } \\
\text { transaction costs. }\end{array}$ \\
\hline $\begin{array}{l}\text { Scepticism regarding } \\
\text { the benefits of CDM }\end{array}$ & $\begin{array}{l}\text { Greene(2006);Kim (2003) } \\
\text { and Angus Reid Consultants } \\
(2006)\end{array}$ & $\begin{array}{l}\text { There seems to be some reticence in raising } \\
\text { climate change onto the national agenda. This is } \\
\text { the principal barrier to the implementation of CDM } \\
\text { projects. South Africa, along with the United States } \\
\text { and Kenya ranked lowest concerning the public } \\
\text { perception regarding, "climate change or global } \\
\text { warming due to the Greenhouse effect". }\end{array}$ \\
\hline
\end{tabular}

The above factors may contribute to the small number of CDM projects in countries that are negatively affected by the above mentioned factors. The empirical part of this research which follows seeks to understand which of the facilitating and inhibiting factors mentioned above have particular importance for South Africa.

\subsection{Responses to the above challenges}

The research set out to determine how South Africa should respond to the CDM opportunities. The literature suggests the following possibilities:

Table 3

Responses to the CDM challenges

\begin{tabular}{|l|l|l|}
\hline $\begin{array}{l}\text { Business to take } \\
\text { leadership role in CDM }\end{array}$ & Nelson (2004) & $\begin{array}{l}\text { Multinational corporations and the energy sector } \\
\text { should take a leading role in the CDM process set by } \\
\text { government. }\end{array}$ \\
\hline $\begin{array}{l}\text { Government to clarify } \\
\text { and streamline national } \\
\text { CDM process }\end{array}$ & $\begin{array}{l}\text { Maruyama (1999) and } \\
\text { Kim (2003) }\end{array}$ & $\begin{array}{l}\text { The case is made for national government to support } \\
\text { potential CDM projects through domestic policies that } \\
\text { encourage closing the gap between potential investors } \\
\text { and project developers. }\end{array}$ \\
\hline $\begin{array}{l}\text { Formal structures to be } \\
\text { implemented to facilitate } \\
\text { communication between } \\
\text { stakeholders }\end{array}$ & $\begin{array}{l}\text { Maruyama (1999); } \\
\text { (2003) and Greene } \\
\text { (2006) }\end{array}$ & $\begin{array}{l}\text { Government is called to work with industry to understand } \\
\text { their different kinds of behaviours around investments } \\
\text { and to increase communication between government } \\
\text { and industry in institutions in order to maximise the } \\
\text { opportunities that exist with the CDM. }\end{array}$ \\
\hline $\begin{array}{l}\text { Increased capacity } \\
\text { building across the CDM } \\
\text { process }\end{array}$ & (Greene, 2005) & $\begin{array}{l}\text { There has been a marked increase in the number of people } \\
\text { involved in the extended CDM supply chain and capacity } \\
\text { building exercises which need to be continued. }\end{array}$ \\
\hline
\end{tabular}


The literature above highlights some of the generic issues experienced by certain countries regarding their suitability to adopting $\mathrm{CDM}$ projects. However the factors for the South African situation need to validated. Although research has been done on the broader subject of climate change and potential carbon based projects in South Africa (SACAN, 2002; Spalding-Fecher, 2002; Bond \& Dada, 2005; Greene, 2006; Jung, 2006) no research has been conducted looking specifically at the aspects supporting or restricting the implementation of CDM projects within South African industry. This was the objective of this research in the hope of assisting the country in achieving greater success with CDM implementation.

\section{4}

Method

Exploratory, qualitative research techniques (Welman \& Kruger, 2001) using semi-structured interviews with subject experts (Fontana \& Frey, 2005 ) were used. The population was limited to experts involved in the CDM process in South African industry. Non-probability, purposive sampling was used including the use of snowball sampling (Welman \& Kruger, 2001). The five groupings of stakeholders were: Industry - Representatives in the companies were all employees that had CDM experience. Seven form this group were interviewed. Government - This group included government officials from both the official CDM structures - viz. the Designated National Authority (DNA) and other departments that served on the inter-ministerial oversight committee and had legislative responsibility in relation to the CDM process. Four from this group were interviewed. Policy Makers -This group comprised individuals who had been instrumental in delivering international capacity building or policy development for government departments on aspects such as sustainable development criteria or the formal CDM processes adopted by the government. Six from this group were interviewed. Project Developers - This group comprised primarily consultants whose source of income and primary business focus are in the identification of opportunities for CDM projects and implementation thereof. Eight from this group were interviewed. Supporting Catalysts - This group comprised people actively involved in the CDM process from a support perspective. They do not have direct ownership of the project, but are critical to the successful implementation of many projects in the country. Five from this group were interviewed.

Thus 30 leading experts were interviewed during a twelve week period from June 2006 to August 2006 using a descriptive interview guideline of open-ended questions. Although the majority of interviews were conducted face to face, three were conducted telephonically and three respondents preferred to exchange views via email.

The data from the interviews were analysed using content analysis (Welman \& Kruger, 2001; Henning, 2004) to extract the main ideas and opinions of the stakeholders. A five point scoring scale was used to convert the stakeholders' comments into a numerical representation of an issue, according to the emphasis imparted by the stakeholder (Fontana \& Frey, 2005). The scale used is shown below.

Table 4

Rating scale

\begin{tabular}{|c|l|}
\hline Value & Ranking criterion \\
\hline 1 & A large discouraging factor \\
\hline 2 & Somewhat discouraging \\
\hline 3 & Neutral towards issue (i.e. neither encouraging nor discouraging) \\
\hline 4 & Somewhat encouraging \\
\hline 5 & A large encouraging factor \\
\hline Blank / null value & Issue was not mentioned \\
\hline
\end{tabular}


This methodology was validated by checking with seven of the respondents for consistency between their intentions and the author's interpretation to minimise researcher bias (Henning, 2004). Finally, qualitative clustering of the issues using a method documented by Goldratt (1994) was performed to establish the macro level issues that are core to the research.

Limitations. The research is focused on South Africa and is therefore not generalisable to any other country. Only practitioners from industry were interviewed, not senior decision makers. Some of the findings regarding the conservative nature or reasons for $\mathrm{CDM}$ not receiving support may therefore be speculative.

\section{5}

\section{Results}

Through the analysis 56 issues were identified with each respondent raising an average of 31.87 issues. A number of issues not revealed by the literature review have been highlighted (e.g. mixed messages on CDM). Once the issues had been established, frequency counts, rating scale means and standard deviations were calculated. The data displayed in Table 5 are rank ordered from the most inhibiting to the most facilitating issue. The count indicates how many interviewees mentioned a specific issue. Factors viewed as positively facilitating CDM in South African industry are evidenced by a high mean $(>4)$. However the majority of factors listed are either inhibiting (i.e. low mean $<2$ ) or have some apparent discrepancy (high standard deviation, $>1$ these are asterisked $*$ in the table below) which indicates that not all stakeholder groups concurred on the issue. Of a total of 956 recorded responses, 641 negative issues (response scores $1 \& 2$ ) were raised, while only 248 positive issues (response scores $4 \& 5$ ) were raised. This concurs with the literature reviewed which also indicated a greater percentage of negative factors. The large number of negative factors is likely to determine the sluggish implementation of industrial CDM projects in South Africa.

Table 5

The 56 identified CDM issues

\begin{tabular}{|r|l|c|c|c|}
\hline & Issue & Mean & SD & Count \\
\hline & Inhabiting factors in South Africa & & & \\
\hline 1 & Aly/trading experience & 1.0 & 0.00 & 3 \\
\hline 2 & Conservative industry/inertia & 1.1 & 0.32 & 19 \\
\hline 3 & Industry understanding of CDM process & 1.3 & 0.45 & 26 \\
\hline 4 & Africa not investment destination & 1.3 & 0.58 & 3 \\
\hline 5 & Mixed messages on CDM & 1.4 & 0.49 & 17 \\
\hline 6 & Business priorities elsewhere (not CDM)/ talk no action & 1.4 & 0.49 & 24 \\
\hline 7 & Bureaucratic process & 1.4 & 0.50 & 22 \\
\hline 8 & Transaction \& monitoring costs & 1.4 & 0.62 & 17 \\
\hline 9 & SA banks do not understand CDM financing & 1.4 & 0.51 & 12 \\
\hline 10 & Complexity of CDM process & 1.5 & 0.59 & 23 \\
\hline 11 & "Cheap" coal power & 1.5 & 0.69 & 20 \\
\hline 12 & Lack of awareness of CDM process & 1.5 & 0.51 & 25 \\
\hline 13 & Post 2012 uncertainty & 0.79 & 28 \\
\hline
\end{tabular}




\begin{tabular}{|c|c|c|c|c|}
\hline 14 & Time to return CERs (2012) & 1.6 & 0.62 & 18 \\
\hline 15 & Success stories/critical CDM mass & 1.6 & 0.51 & 16 \\
\hline 16 & Legislation & 1.6 & 0.81 & 16 \\
\hline 17 & Eskom policies & 1.6 & 0.81 & 16 \\
\hline 18 & SA slow with DNA/KP & 1.6 & 0.69 & 19 \\
\hline 19 & Silos in capacity & 1.6 & 0.87 & 25 \\
\hline 20 & Industry capex (economic) focus & 1.6 & 0.72 & 23 \\
\hline 21 & Additionality & 1.6 & 0.86 & 21 \\
\hline 22 & ID correct projects & 1.7 & 0.95 & 10 \\
\hline 23 & Expensive to keep up to date with CDM developments & 1.7 & 0.47 & 11 \\
\hline 24 & Tax on CERs & 1.8 & 0.73 & 13 \\
\hline 25 & US \& Aus excluded/multinationals & 1.8 & 0.75 & 6 \\
\hline 26 & SA do not see CC as real & 1.8 & 0.69 & 13 \\
\hline 27 & Methodology applicability to SA & 1.9 & 0.93 & 20 \\
\hline 28 & Volatility of CER prices & 1.9 & 0.95 & 14 \\
\hline 29 & Incentives for industry & 1.9 & 0.73 & 18 \\
\hline 30 & EIA/NER/IPP Process & 1.9 & $1.08^{*}$ & 19 \\
\hline \multirow[t]{2}{*}{31} & Govt guidance & 2.0 & $1.21^{*}$ & 25 \\
\hline & Neutral factors or factors having a large discrepancies in ratings & & & \\
\hline 32 & Govt:Industry cooperation & 2.1 & 0.94 & 20 \\
\hline 33 & DNA effectiveness in promoting CDM & 2.2 & $1.01^{*}$ & 26 \\
\hline 34 & Industry leadership & 2.3 & $1.37^{*}$ & 24 \\
\hline 35 & Civil society (NGOs) & 2.4 & $1.36^{*}$ & 11 \\
\hline 36 & Govt capacity & 2.4 & $1.08^{*}$ & 25 \\
\hline 37 & Govt leadership & 2.5 & $1.29 *$ & 28 \\
\hline 38 & SA SD \& BEE requirements & 2.6 & $1.21 *$ & 19 \\
\hline 39 & Foreign finance attractive to small companies only/available & 2.7 & $1.25^{*}$ & 13 \\
\hline 40 & Climate change a real issue & 2.7 & $1.68^{*}$ & 11 \\
\hline 41 & CDM capacity in SA & 2.7 & $1.46^{*}$ & 27 \\
\hline 42 & Technology transfer & 3.6 & $1.13^{*}$ & 7 \\
\hline 43 & SA economy growth & 3.6 & $1.69 *$ & 8 \\
\hline 44 & DNA in DME & 3.6 & $1.22 *$ & 17 \\
\hline 45 & Price of CERs & 3.8 & $1.24^{*}$ & 16 \\
\hline
\end{tabular}




\begin{tabular}{|r|l|r|r|c|}
\hline & Facilitating factors in South Africa & & & \\
\hline 46 & Best destination in Africa for foreign CDM & 4.2 & 0.63 & 10 \\
\hline 47 & Increased media coverage of CC \& CDM & 4.2 & $1.03^{*}$ & 10 \\
\hline 48 & Growth of CER market/Money & 4.2 & 0.94 & 18 \\
\hline 49 & Old technology ready for replacement & 4.3 & 0.70 & 15 \\
\hline 50 & Energy crisis & 4.4 & 0.74 & 8 \\
\hline 51 & Political stability & 4.4 & 0.53 & 7 \\
\hline 52 & SA infrastructure & 4.5 & 0.52 & 15 \\
\hline 53 & Corporate governance & 4.5 & 0.52 & 11 \\
\hline 54 & Potential for renewable \& energy efficiency & 4.6 & 0.50 & 29 \\
\hline 55 & Ratification of Kyoto by SA & 4.6 & 0.51 & 15 \\
\hline 56 & Large emitters & 4.8 & 0.41 & 24 \\
\hline
\end{tabular}

\section{6}

\section{Analysis}

Subsequent to the content analysis, the 56 identified issues were clustered into 11 macro factors based on the literature (Goldratt, 1994) in order to make the data more manageable and usable. Each of the 56 issues in Table 5 has been mapped onto one of the clusters. Boxplots were analysed of the means for each of the composite issues in each of the factors, allowing the factors to be classified as regarded either inhibiting or facilitating based on the interviewees' responses. The list of associated issues for each clustered factor is presented in Table 6 .

\section{Table 6}

Clustered factors and associated issues

\begin{tabular}{|c|c|c|c|}
\hline & Clustered factor & Stakeholder issue & Classification \\
\hline 1 & $\begin{array}{l}\text { Kyoto Protocol requirements } \\
\text { and processes }\end{array}$ & $\begin{array}{l}\text { - } \text { Additionality } \\
\text { - } \text { Post } 2012 \text { uncertainty } \\
\text { - } \text { Expensive to keep up to date with CDM } \\
\text { developments } \\
\text { - } \text { Complexity of CDM process } \\
\text { - } \text { Methodologies applicable to SA } \\
\text { - } \text { Bureaucratic process } \\
\text { - } \quad \text { Transaction costs } \\
\text { - } \quad \text { USA \& Australia outside Kyoto }\end{array}$ & Inhibiting \\
\hline 2 & Carbon markets & $\begin{array}{l}\text { - Volatility of CER price } \\
\text { - Growth of CER market / money } \\
\text { - } \text { Price of CERs } \\
\text { - } \quad \text { Time to return CERs }\end{array}$ & Facilitating \\
\hline
\end{tabular}




\begin{tabular}{|c|c|c|c|}
\hline 3 & South African infrastructure & $\begin{array}{l}\text { - } \text { SA Economic growth } \\
\text { - } \text { Political stability } \\
\text { - SA infrastructure developed } \\
\text { - Africa not a significant international } \\
\text { investment destination } \\
\text { - SA best investment destination in Africa } \\
\text { - No SA experience in AlJ or emission trading } \\
\text { - Role of civil society / NGOs } \\
\text { - Attractiveness of foreign direct investment } \\
\text { - }\end{array}$ & Facilitating \\
\hline 4 & $\begin{array}{l}\text { SA Government } \\
\text { infrastructure }\end{array}$ & $\begin{array}{l}\text { - No direct legislation covering CDM } \\
\text { - No formal incentives to industry to } \\
\text { implement CDM } \\
\text { - } \quad \text { EIA / IPP processes } \\
\text { - Potential taxation of CERs } \\
\text { - } \text { Government leadership }\end{array}$ & Inhibiting \\
\hline 5 & SA Energy infrastructure & $\begin{array}{l}\text { - Cheap coal power } \\
\text { - Eskom policies }\end{array}$ & Inhibiting \\
\hline 6 & SA CDM capacity & $\begin{array}{l}\text { - } \text { CDM capacity in South Africa } \\
\text { - Silos in capacity } \\
\text { - SA banks not understanding CDM finance }\end{array}$ & Facilitating \\
\hline 7 & Government CDM processes & $\begin{array}{l}\text { - } \text { SA ratified Kyoto Protocol } \\
\text { - } \text { DNA in DME } \\
\text { - SA slow to form a DNA } \\
\text { - } \text { DNA effectiveness in promoting CDM } \\
\text { - } \text { Government guidance } \\
\text { - } \text { Government capacity } \\
\text { - } \\
\text { Sustainable devt \& BEE requirements }\end{array}$ & Facilitating \\
\hline 8 & SA industry infrastructure & $\begin{array}{l}\text { - } \text { Corporate governance } \\
\text { - Conservative industry / inertia } \\
\text { - Potential for renewable energy / energy } \\
\text { - } \text { efficiency } \\
\text { - } \text { Old technology ready for replacement } \\
\text { - Industry economic focus }\end{array}$ & Facilitating \\
\hline 9 & SA industry CDM response & $\begin{array}{l}\text { - Industry leadership } \\
\text { - Industry understanding of CDM process } \\
\text { - } \text { Technology transfer } \\
\text { - Identification of correct projects } \\
\text { - Business priorities elsewhere (not CDM) } \\
\text { - } \quad \text { Lack of success stories / critical CDM mass }\end{array}$ & Inhibiting \\
\hline
\end{tabular}




\begin{tabular}{|c|c|c|c|}
\hline 10 & $\begin{array}{l}\text { Industry / government } \\
\text { interface }\end{array}$ & - Government : industry cooperation & Inhibiting \\
\hline 11 & Public \& media perceptions & $\begin{array}{l}\text { - } \text { Climate change is a real issue } \\
\text { - Increased media coverage of global warming } \\
\text { issues } \\
\text { - } \quad \text { Lack of awareness of CDM process } \\
\text { - } \text { Mixed messages on CDM \& climate change } \\
\text { - South Africa does not perceive climate as a } \\
\text { real issue }\end{array}$ & Inhibiting \\
\hline
\end{tabular}

It is on these 11 clustered factors and the data from Table 5 that the remaining analysis and qualitative discussion of this research are based. Use is made of the results of the quantitative content analysis, the clustering exercise and illustrative quotations from the respondents in the discussion of the results.

At the outset it is interesting to note that one of the project developers stated that "when one looks at South Africa's projects on a per capita, per ton of carbon mitigated, South Africa is actually doing very well at the CDM process." This is an interesting metric and encouraging. However, on absolute numbers and progress of monetisation of projects, as well as in the vast number of issues raised by those interviewed, South Africa is lagging behind many of its comparable non-Annex I counterparts involved in the CDM.

\subsection{Facilitators}

The factors that have been found to encourage industrial CDM project implementation in South Africa are:

The active and growing carbon market and prices available are encouraging industry to implement CDM projects. A supporting catalyst said "CDM smells like the environment, but it is business; it is both, yet neither. There is money, lots of money to be made." Even small projects in South Africa like the Kuyasa housing project in Cape Town have been sold into Europe for, "around $€ 14$ per ton." This gives a return of around $€ 84,000$ per annum to the project. Taking into consideration that other projects in South Africa should on average return 166,000 CERs per annum (United Nations Environment
Programme, 2006) at a cost of $€ 10$ per CER, an average return of around $€ 1,660,000$ per annum can be expected from each project. These are significant figures and are motivating a number of the stakeholders involved in project development. This supports the general view of researchers (Greiner \& Michaelowa, 2003; Matsushashi et al., 2004; Greene, 2005; Dagoumas et al., 2006; Jung, 2006 and Ellis et al., 2007) that have previously identified the income from the sale of carbon credits as a positive factor.

South Africa has a favourable established infrastructure that facilitates the implementation of industrial CDM projects. Over the past decade, South Africa has had a period of economic growth and political stability. Set inflationary and fiscal growth targets were met and the economic growth looks set to continue into the future. Well-established infrastructure including telecommunication networks; transportation networks for road, rail, air and sea; an advanced banking system; access to educated employees and expertise and availability of raw materials all contribute to South Africa's favourable position. All other conditions being equal, any foreign investors should have a high confidence in launching a project here compared to a number of other developing countries. Spalding-Fecher (2002) Davidson et al. (2003); Jung (2006) and Greene (2006) all support this view. However, even with the enabling infrastructure, one of the supporting catalysts made the following comment "With the economic growth, industry had no need to look at CDM projects because they were making money on their core business. You need a bit of a squeeze and downturn for them to look at other options, such as CDM." 
South Africa has a favourable industrial baseline: Many of the industrial manufacturing companies are very energy intensive and the plants have been in operation for many years, thus not particularly energy efficient. These are ideal components for CDM projects that are aimed at improving energy efficiency and mitigating greenhouse gas emissions. Many South African industries are either multinationals or publicly listed on the Johannesburg Stock Exchange (JSE). As such they are required to apply corporate governance principles to their undertakings. This puts more stakeholder driven pressures and requirements on industry to implement projects to reduce greenhouse gases.

CDM capacity exists within South Africa to facilitate the implementation of industrial CDM projects. One of the policy makers made reference to, "ten odd capacity building exercises aimed at capacity building in industry have all taken place." Although there has been sufficient capacity building to develop a good understanding of the CDM process in South Africa, more practitioners with experience are needed. Another policy maker referred to the problem as being, "gaps of information across the board. No one seems to have the full picture of what is going on in CDM in South Africa." To most stakeholders the existence of capacity silos was an issue. Although Greene (2005); Greene (2006) and Davidson et al. (2003) refer to capacity, they do not delve into the possibility of silos or capacity facilitating more projects in the country.

Government CDM processes exist to facilitate the implementation of industrial CDM projects. The Designated National Authority (DNA) was complimented for its efforts at streamlining and facilitating the CDM processes. One of the developers who had experience with CDM projects in other countries stated that, "the DNA should just facilitate the process ... Industry needs to take the lead. The (South African) DNA is better than most." Industry stakeholders all mentioned that their interactions with the DNA had been mostly positive with anticipated deadlines being met. One industry stakeholder mentioned that the DNA, "lacked some capacity and needs to be more consistent." This lack of consistency relates more to an interpretation of sustainable development criteria than capacity. Spalding-Fecher (2002); Greene (2006) and Jung (2006) all state that effective government $\mathrm{CDM}$ processes are a prerequisite for the implementation of CDM projects.

\subsection{Inhibitors}

The factors via the interviews that were found to discourage industrial CDM project implementation in South Africa are:

United Nations requirements for CDM projects are complex. Various issues were raised regarding $\mathrm{CDM}$ being an overly complex bureaucratic process, the additionality requirements are difficult to interpret and transaction costs prohibitively high. Most of these individual issues were raised by more than 20 respondents. These processes are not unique to South Africa. All developing countries (non-Annex I) are subject to the same guidelines and regulations. However, a number of these countries have grasped these regulations and are surpassing South Africa in the implementation of industrial CDM projects as discussed in the literature above.

Kyoto Protocol post 2012. A policy maker said "2012 is a massive issue. Many projects work over 15 years (to 2020) but not over 7 years (to 2012)." Industry needs to be active in lobbying government to represent the needs of the country at the COP/MOP meetings to ensure that South Africa has a favourable future place in the post 2012 scheme.

Ineffective government procedures hinder industrial CDM implementation. The issue of the government's leadership role in the CDM process was raised by 28 out of 30 stakeholders. The two greatest components of this factor are that global warming and climate change do not enjoy national priority and ancillary processes that are required to register a CDM project (such as an EIA) are extremely onerous. One of the project developers summarised it by saying, "Since 1994 there has just been too much noise on the national agenda. BEE, unemployment, crime, poverty, AIDS have just crowded CDM out of the picture." A policy maker summarised 
others' ideas, "there are often just too many hoops to jump through." Not only national government is involved, but often provincial and local government structures need to give approval too, further complicating the process and adding to the frustration. If government could align these processes it would help to streamline the registration of more industrial CDM projects. Two thirds of stakeholders mentioned the additional governmental requirements over and above the normal CDM project cycle. These include the environmental impact assessment (EIA), the need to get permission to operate as an independent power producer (IPP). A function that the government has been slow to leverage has been the promotion of CDM in South Africa. The Promotions Sub-Committee of the DNA was only formalised during 2006 and the effectiveness of this committee will further encourage the implementation of CDM projects.

Relatively low local industrial electricity costs and energy policy discourage industry from implementing CDM projects: A negative issue raised by 15 respondents was that of the national power utility, Eskom's policies and 18 respondents noted the availability of cheap industrial coal based electricity. South African industry is very energy intensive and traditionally has received some of the cheapest electrical power in the world (Greene, 2006) with many of the externalities excluded in the pricing. This has led to a disincentive to save power in comparison to many other countries. Industry stakeholders related that governmental policy needs to actively promote renewable energy and smaller power producers. South Africa needs to encourage a culture of both electricity saving and renewable energy. Eskom has attempted to promote renewable energy and energy efficiency through various mechanisms and continues with initiatives such as demand side management (DSM). An encouragement is that Eskom is actively involved in the CDM process, with four projects in advanced stages of development (interview with Rambharos, 2006).

A lack of understanding and a conservative approach which does not encourage implementation of non-core business initiatives such as CDM projects leads to South African business not responding proactively to CDM. This issue was raised by 26 of the 30 stakeholders. One policy maker put it this way, "there are a whole bunch of young 'techies' and enthusiasts on the fringe looking at $\mathrm{CDM}$, but no core management and decision makers involved." Internal processes including financing of carbon projects, a good understanding of the CDM process and the strategic importance of this at board level, need to be driven into companies. Resistance to change from senior management was also mentioned by a number of the middle managers in industry that were interviewed. Conservativism in South African industry is an issue that has previously only been raised by Greene (2006), but the data suggest that it is far more important an issue than previously considered in the South African context considering that 19 respondents mentioned it.

After four years there are still no successful industrial projects in the country. A few have reached the registration phase, but none have realised a significant monetary value from the process yet. An industry stakeholder referred to this as a lack of "adequate role models, we need success stories, success breeds success, whereas a lack of success breeds scepticism." Much of the responsibility for this inactivity was placed on the response of industry itself and not on factors external to it.

A gap exists between industry and government as regards communication and collaboration around industrial CDM projects. The CDM process requires any industrial CDM project developers to interface with government at a number of points in the process. These interactions vary from dealing with the designated national authority (DNA), a possible environmental impact assessment (EIA), licensing as an independent power producer (IPP) to potential taxation and foreign exchange requirements for project financing. A certain amount of suspicion and cynicism traditionally exists between the two bodies. Maruyama (1999), Nelson (2004) and Kim (2003) contend that communication gaps are likely to exist between the various stakeholder groups, especially project developers and government. 
Industry has the most to gain from the process and needs to drive it. Two thirds of respondents mentioned this as an issue. One government official stated, "We need to move away from a blaming culture. All parties need to sit down as a collective and discuss the issues. Only then can a way forward be charted, and this will benefit the whole country." Although most groupings felt that cooperation was an inhibiting factor, the supporting catalysts generally had a positive view that there was cooperation between the parties and this was accelerating implementation.

Scepticism exists in South Africa regarding the causes and seriousness of the impact of climate change, leading to reservations regarding the benefits of implementing industrial CDM projects. As one supporting catalyst commented, "The media plays a major role in the response to global warming. A lot of the reporting is sensationalist and damaging to people trying to get CDM going." Just as knowledge transfer is required in industry, so too journalists and editors need to be educated on the CDM, global warming, climate change and the need to respond to it. This issue was raised by 17 stakeholders from all groupings. This was supported by Angus
Reid Consultants (2006) who found there is a large portion of the population that does not perceive global warming and associated climate change to be either real, or serious enough to make changes.

\section{7}

\section{Discussion of results}

In order to consolidate the findings and to add value a matrix was developed that offers a framework for positioning and ranking the relative significance of the factors. This is a qualitative, illustrative matrix and is offered as a baseline for further discussion and research. The matrix has two components: $\mathbf{X}$-axis: The ease of change of influence of a factor on an industrial CDM project. After examining and developing an understanding of the literature, the data were placed in the matrix. Y-axis: The factor either positively (facilitative) or negatively (inhibiting) affects the implementation of CDM projects in South African industry. The data were placed according to the mean scores of the factors. The 11 consolidated factors were transposed onto the matrix in Figure 1 for illustration and discussion purposes.

Figure 1

Matrix of clustered factors

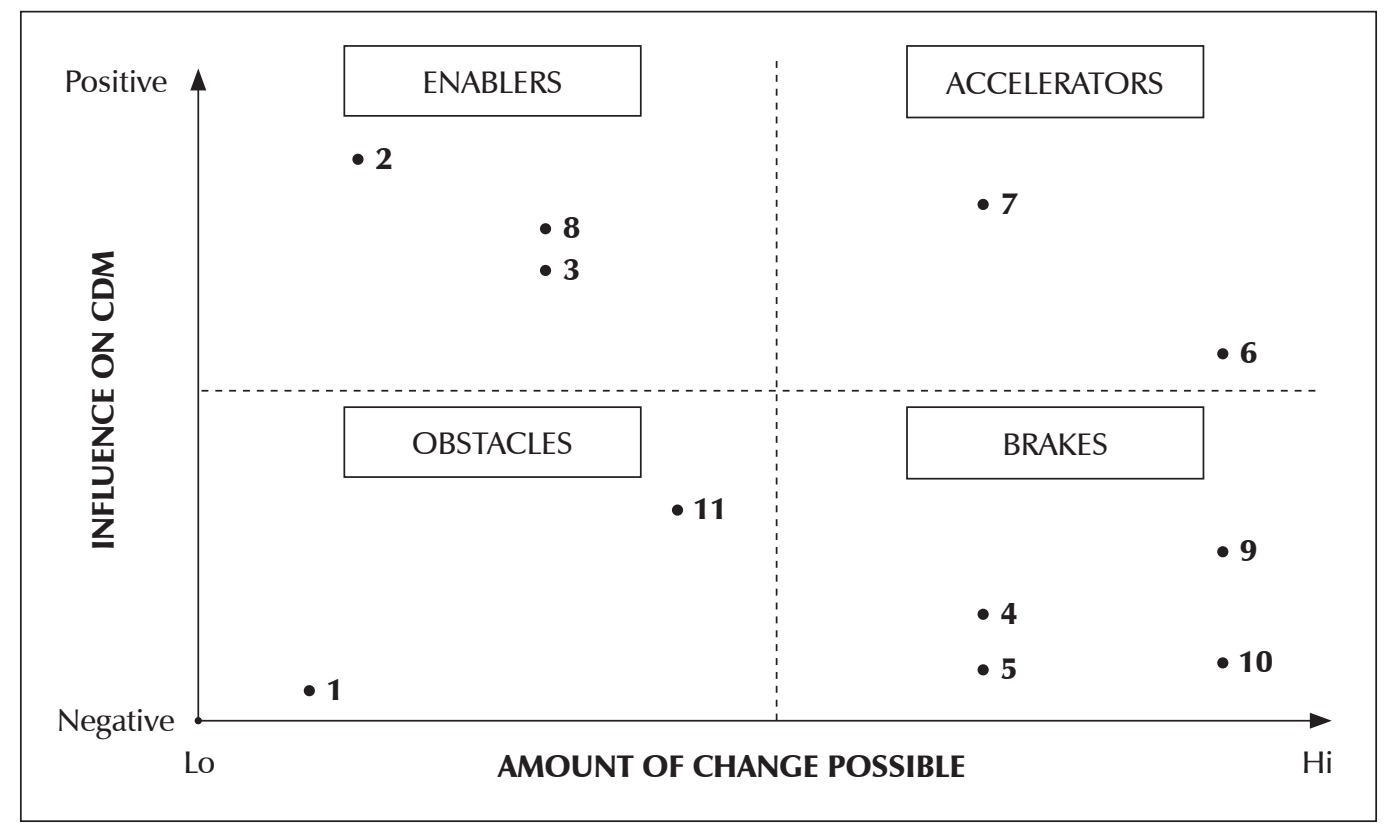


The four quadrants have been designated as: Obstacles, Enablers, Brakes and Accelerators. Dependent on the quadrant that a factor resides in, an approach is proposed to apply interventions that will have the most impact on accelerating the implementation of industrial CDM projects in South Africa.

Obstacles are those factors that cannot easily be changed, yet there is little or no opportunity to exclude their negative influence on the implementation of an industrial CDM project. They include such factors as the high transaction costs, the complexity and the bureaucratic nature of the CDM process and the influence of the media and public perception. Currently this acts as an obstacle with the mixed messages and scepticism regarding the seriousness of the impacts of climate change and the need for action. The following interventions are required to address the effects of an obstacle. Firstly, an understanding of the obstacles. It is easier to address and counteract specific problems than a large nebulous problem. A useful methodology for this in all the quadrants is a SWOT analysis. One could develop procedures to exploit any opportunities and strengths while mitigating the weaknesses and threats and identify where input is to be given into structures (such as national working groups) to influence any changes that may occur. As an example one could look at the high transaction costs involved in an industrial CDM project implementation. Understanding the amounts and comparing these with expected returns, allows a project developer to set an acceptable minimum limit of expected CERs to be realised. This may be in the region of $20,000 \mathrm{tCO}_{2} \mathrm{e}$ per annum. If a project realises anything less than this, the developer need not spend further time or resources on pursuing that CDM process.

Enablers are very similar to obstacles in that there is little possibility to change their influence on the implementation of industrial CDM projects, but they exert a positive influence on the process. The enablers identified include the South African infrastructure which provides access to expert services and networks. The existence of large greenhouse gas emitting industries afford many opportunities for the implementation of industrial CDM projects.
The development of a large international carbon market and the possibility of acceptable financial returns is also an enabler. As with the case of the obstacle, change does not occur easily with an enabler. Once more it is important to understand the role of enablers in order to be able to maximise their influence on the implementation of industrial CDM projects. An example of this would be analysing one's industry. Within the industry there may be opportunities for CDM projects in three areas (e.g. energy efficiency, solar heating and a complex industry specific process).

The following two quadrants have the potential to be changed and move vertically from one quadrant to the other. Brakes are defined as those factors that hold back the implementation of industrial CDM projects, but have the potential to accelerate their implementation. By their nature, change is possible, provided the proper interventions are made to address the issues that are retarding the CDM process. Factors located in this quadrant include the gap that exists in the interactions between industry and government; the energy policies and infrastructure in the country and the slow response by industry to implement $\mathrm{CDM}$ projects due to conservativeness and a lack of focus and understanding of CDM opportunities. Change should be focussed on collective action and be part of implementation strategies of individual companies. An example of this would be the negative perceptions and understanding of decision makers in a company. In order to change their input from being inhibitive, in depth knowledge transfer sessions could be delivered in order to empower them to understand the opportunities that CDM can offer. Doing so could move this factor from being a brake to a potential accelerator that boosts the implementation process and could give the company a potential strategic advantage. The same is true for issues that require collective action, like government processes of approving environmental impact assessment. Empowered task teams with multi stakeholder involvement could be set up to ensure that recommendations are made and implemented.

The final quadrant contains the accelerators. These are the factors that are most encouraging 
to the implementation of industrial CDM projects. They are the factors that allow project developers to achieve a successful CDM project that mitigates greenhouse gas emissions, promotes sustainable development and is a source of income from the sale carbon credits (CERs) on the carbon market. They include the capacity in the country and the government's processes that are currently encouraging CDM. Due to their position on the right hand half of the matrix, they are volatile and vulnerable to change. Not all change is positive, so if for example the government CDM authority (DNA) requires more restrictive sustainable development or does not employ competent resources, the current accelerator will migrate to the brake quadrant and act as an inhibitor rather than accelerator. Accelerators are the factors that any project developer naturally wants to make use of. These are the factors that need to be analysed and then aligned with the strategic and tactical plans of the industry. The ideal situation is to maintain the factor's positioning in the upper right quadrant and to reinforce its position there. An example of this is the CDM capacity that is available in South Africa. There are a number of competent practitioners in South Africa but many do not have experience across the full spectrum of the CDM process. Industries wanting to implement CDM projects need to identify the skills available in the pool and link in experts to complement the successful achievement of the overall project.

\subsection{The way forward}

The matrix is a practical starting point for industries getting involved in the CDM process. Certain facets of this model will need to be expanded and quantified as this matrix gives a view on the high level strategic factors affecting the CDM process. The interventions that have been found to accelerate the implementation of CDM in South African industry are:

- A clear understanding of the Kyoto mechanisms and of the opportunities for South Africa needs to be developed by all stakeholder groups.

- The national processes supporting CDM need to be streamlined by government to facilitate project implementation and climate change linked to national government objectives as discussed above. One of the views of a policy maker was "We need climate change on the national agenda if things are really going change, then we can use CDM to achieve goals such as renewable energy targets".

- South African energy market needs to be opened to reduce Eskom's and fossil based power dominance. A policy maker felt, "Smaller players need to supply power easier and a renewable energy market needs to be developed."

- Business should take the lead and drive CDM in South Africa. A supporting catalyst stated that, "the captains of industry have been acting like this is a load of old crock. They need to wake up and act." A policy maker suggested "Eskom needs to take the lead, they are a parastatal and have the biggest potential gain.”

- Formal structures to facilitate communication between stakeholders to prevent a silo mindset in knowledge and capacity. As one government stakeholder said, "We all need to engage and optimise all key players' inputs ... We need to move away from a blaming culture." A policy maker suggested a high level Indaba (meeting), "The captains of industry need to meet with really influential people, like the top 10 thinkers on business and climate change, and come up with a strategic plan."

- Successful industrial CDM projects are required to encourage further project activity: A developer said, "we need a lot more experience so that more projects can be tackled. It's a bit of a catch 22 situation at the moment." Another comment by a policy maker was that, "capacity building needs to be focussed on actual projects now. We need to move away from workshops and reports to action."

- Promotion of CDM to change perceptions in the media and public. A government stakeholder stated, "we need awareness, lots and lots of awareness on CDM. The promotions sub committee of the DNA has a really important role to play." 
- Learnings from successful non-annex 1 countries. A supporting catalyst commented that, "We need to go to Brazil and India and learn from them. What are they doing that we could apply to promote CDM in South Africa?"

\section{8}

\section{Conclusion and further research suggestions}

It is recommended that research be conducted in the follow areas: To explore the corporate inertia specifically around industry response to climate change; An examination of the factors that have accelerated industrial CDM project implementation in countries that lead South Africa. The authors contend that not having any successful projects for business to observe and compare to is limiting involvement in the process. As successful CDM projects are implemented by South African industries and then documented and studied, they will act as a catalyst to promote additional projects. It is also contended that for CDM to become entrenched in industry, it needs to be a core business objective in the interest of society at large and not merely an "add-on" for publicity or goodwill. The value of knowledge is not so much in the creation of new knowledge, but in the practical application thereof in order to make a difference in the world. It is hoped that in some small way this research can contribute to the betterment of our country and the global environment.

\section{References}

1 ANGUS REID CONSULTANTS (2006)

"Globescan poll: Global views on climate change", United States: Angus Reid Consultants. Available from: http://www.angus-reid.com/admin/collateral/ pdfs/polls/WPO_GlobalWarming.pdf (accessed 03/05/2006).

2 BOND, P. \& DADA, R. (eds.) (2005) Trouble in the Air. Global Warming and the Privatised Atmosphere. A Civil Society Energy Reader, Centre for Civil Society: Durban.

3 CAPOOR, K. \& AMBROSI, P. (2006) State and Trends of the Carbon Market 2006, (Update:
January 1-September 30, 2006) International Emissions Trading Association (IETA) and The World Bank: Washington D.C.

4 COGAN, D.G. (2006) "Corporate governance and climate change: Making the connection”, CERES: Boston, Available from: http://www.ceres.org/pub/ docs/Ceres_corp_gov_and_climate_change_0306. pdf (accessed 21/04/2006).

5 DAGOUMAS, A.S.; PAPAGIANNIS, G.K. \& DOKOPOULOS, P.S. (2006) "An economic assessment of the Kyoto Protocol application", Energy Policy, 34: 26-39.

6 DAVIDSON, O.; HALSNÆS, K.; HUQ, S.; KOK, M.; METZ, B.; SOKONA, Y. \& VERHAGEN, J. (2003) "The development and climate nexus: The case of sub-Saharan Africa”, Climate Policy, 3S1: S97-S113.

7 ELLIS, J.; WINKLER, H.; CORFEE-MORLOT, J. \& GAGNON-LEBRUN, F. (2007) "CDM:

Taking stock and looking forward", Energy Policy, 35: 15-28.

8 FONTANA, A. \& FREY, J.H. (2005) "Chapter 27: The interview - From neutral stance to political involvement", in Denzin, N.K. \& Lincoln, Y.S. (eds.) The Sage Handbook of Qualitative Research, ( $3^{\text {rd }}$ ed.) Sage: London.

9 GOLDRATT, E.M. (1994) It's Not Luck, Creda Press: Cape Town.

10 GREENE, W. (2005) Carbon Finance for Africa - An Investor's Guide, Africapractice: London.

11 GREENE, W. (2006) Carbon Finance for South Africa - An Investor's guide. Africapractice: London.

12 GREINER, S. \& MICHAELOWA, A. (2003)

"Defining investment additionality for CDM projects - practical approaches", Energy Policy, 31: 1007-1015.

13 HENNING, E. (2004) Finding Your Way in Qualitative Research, Van Schaik: Pretoria.

14 INTERGOVERNMENTAL PANEL ON CLIMATE CHANGE (IPCC) (2001) IPCC Third Assessment Report. Climate Change 2001: Synthesis Report. Summary for Policymakers, IPCC: Wembley, United Kingdom.

15 JUNG, M. (2006) "Host country attractiveness for CDM non-sink projects”, Energy Policy, 34: 21732184.

16 KAMEL, S (ed.) (2005) CDM PDD Guidebook: Navigating the Pitfalls, UNEP: Denmark.

17 KIM, J.A. (2003) "Sustainable development and the CDM: A South African case study", Tyndall centre for climate change research: United Kingdom, Working Paper 42, Available from: http:// www.tyndall.ac.uk/publications/working_papers/ wp42.pdf (accessed 24/01/2006). 
18 MARUYAMA, A. (1999) "Potentials and constraints of private sector participation in the CDM", ESCAP Regional seminar on promotion of energy efficiency in industry and financing of related public and private investments. Institute for Global Environmental Studies (IGES): Bangkok.

19 MATSUSHASHI, R.; FUJISAWA, S.; MITAMURA, W.; MOMOBAYASHI, Y.\& YOSHIDA, Y. (2004) "Clean development mechanism projects and portfolio risks", Energy, 29: 1579-1588.

20 MAXWELL, T.J. (2006) "Corporate governance and sustainability: Board management for strategic responses to climate change", unpublished doctoral thesis; Graduate School of Business Administration: University of St. Gallen

21 MICHAELOWA, A.; STRONZIK, M.; ECKERMANN, F. \& HUNT, A. (2003) "Transaction costs of the Kyoto mechanisms", Climate Policy, 3: 261-278.

22 NELSON, P. (2004) "An African dimension to the clean development mechanism: Finding a path to sustainable development in the energy sector", Denver Journal of International Law and Policy, 32 (4): 615-652.

23 NJOBENI, S (2006) "SA tardy in signing up for carbon credits", Business Day, 12 July.

24 SONNEBORN, C.L. (2004) "Renewable energy and market based approaches to greenhouse gas reduction - opportunity or obstacle?" Energy Policy, 32: 1799-1805.

25 SOUTH AFRICAN CLIMATE ACTION NETWORK (SACAN) (2002) "Can we justify selling Africa's atmosphere?" SACAN (July), Sustainable Energy \& Climate Change Partnership.

26 SPALDING-FECHER, R. (ed.) (2002) The CDM Guidebook: A Resource for Clean Development Mechanism Project Developers in Southern Africa ( $2^{\text {nd }}$ ed.), University of Cape Town: Cape Town.

27 THE CLIMATE GROUP (2005) Carbon Down Profits $U p$ ( $2^{\text {nd }}$ ed.) HSBC: United Kingdom.

28 UNITED NATIONS (1997) Kyoto Protocol to the United Nations Framework Convention on Climate Change, United Nations: New York.

29 UNITED NATIONS (2001) Report on the Conference of Parties on its seventh session held at Marrakesh 29 October to 10 November 2001, United Nations: New York. Available from: http://unfccc. int/resource/docs/cop7/13a02.pdf (accessed 24/01/2006).

30 UNITED NATIONS ENVIRONMENT PROGRAMME (2006) Capacity Development for CDM (CD4CDM) - CDM Pipeline overview (updated 9 August 2006). UNEP RIS $\varnothing$ Centre: UNEP Available from: http://cd4cdm. org/Publications/CDMpipeline.xls (accessed 23/09/2006).

31 VIGUIER, L.L. (2004) "A proposal to increase developing country participation in international climate policy”, Environmental Science \& Policy, 7 : 195-204.

32 WELMAN, J.C. \& KRUGER, S.J. (2001) Research Methodology ( $2^{\text {nd }}$ ed.) Oxford University Press: Cape Town.

33 WORLD BUSINESS COUNCIL FOR SUSTAINABLE DEVELOPMENT (WBCSD) AND WORLD RESOURCES INSTITUTE (WRI) (2004) The Greenhouse Gas Protocol: A Corporate Accounting and Reporting Standard (Rev. ed.) WRI and WBCSD Press: USA.

34 WORLD BUSINESS COUNCIL FOR SUSTAINABLE DEVELOPMENT (WBCSD) (2004) Facts and Trends. Energy and Climate Change, WBCSD: Switzerland. 